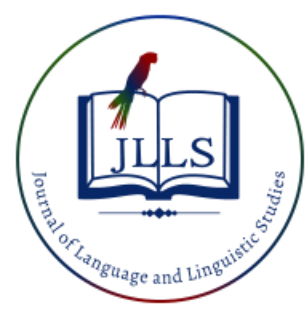

Available online at www.jlls.org

JOURNAL OF LANGUAGE AND LINGUISTIC STUDIES

ISSN: $1305-578 \mathrm{X}$

Journal of Language and Linguistic Studies, 16(4), 1774-1783; 2020

\title{
More than words: A documentation and a morphological analysis of an indigenous language in the Philippines
}

\author{
Evalyn Bonquin Abiog a 1 iD, Rowena David ${ }^{\mathrm{b}}$ \\ ${ }^{a}$ University of Santo Tomas, Manila, Philippines \\ ${ }^{b}$ Burog Elementary School in Bamban, Tarlac, Philippines
}

\section{APA Citation:}

Abiog., E.B., \& David, R. (2020). More than words: A documentation and a morphological analysis of an indigenous language in the Philippines. Journal of Language and Linguistic Studies, 16(4), 1774-1783.

Submission Date:26/06/2020

Acceptance Date:29/07/2020

\begin{abstract}
More than words are stories to be told. Stories tell a lot about people's thoughts, experiences, and practices which in turn speak about people's language, identity, and cultural heritage. The present study deals with the documentation and analysis of Mag-Antsi, the native language of Ayta Mag-Antsi indigenous people in the Philippines. With the aging population as its remaining speakers, Mag-Antsi is far from being sustainable. Using in-depth interviews, Ayta beliefs, practices, and traditions were documented and a word list of 376 Mag-Antsi words with varied lexical categories was constructed. A morphological analysis of Mag-Antsi was done to capture the grammatical structure of Mag-Antsi words in the oral narratives. Ten cultural short stories were also developed from the oral narratives to document and preserve the distinct culture of Ayta Mag-Antsi. This study found that the morphological structure of Mag-Antsi language has some similarities with Filipino which is marked by inflections and a unique orthography. This study also shows practical implications to the use of mother tongue in the academic setting and to language preservation.
\end{abstract}

(C) 2020 JLLS and the Authors - Published by JLLS.

Keywords: Mag-Antsi; Ayta Mag-Antsi; word list; cultural short stories; mother tongue

\section{Introduction}

With 8,200 speakers of the language (Ethnic Group Philippines, 2011), Mag-Antsi, the native language of Ayta Mag-Antsi indigenous community, is currently considered as a stable language. Despite its stability, Mag-Antsi is is not considered sustainable because majority of the Mag-Antsi speakers from Central Luzon, Philippines are Ayta Mag-Antsi elders. The children seldom use their native language both at home and in schools. To date, no academic books have been written in MagAntsi that Ayta students are using in schools. Conversely, the students also do not use Mag-Antsi in schools because their teachers mostly speak Kapampangan, one of the ethnolinguistic languages in Central Luzon. Academic books are also written either in Kapampangan and Filipino. As there have been no written narratives in Mag-Antsi that can be used by students, the preservation of Mag-Antsi will

\footnotetext{
1 Corresponding author.

E-mail address: ebabiog@ust.edu.ph
} 
be far from sustainable. Worse, this language could reach the level of extinction if only the aging population continues to use Mag-Antsi.

Narratives have been proven by research to be effective in preserving a culture. Oral narratives provide indigenous peoples more opportunities to take ownership of research and become empowered individuals of their community (Iseke, 2013). People are drawn to stories because they see themselves reflected in them (TCK, 2020). Short stories in the form of written narratives not only immortalize people's culture but also preserve their language. Through cultural short stories written in the native language of the indigenous community, both the language and culture come alive in print to be learned, treasured, and enjoyed by younger generations. Conversely, this study documented the narratives of Ayta Mag-Antsi in order to sustain their native language.

\subsection{Significance of the Study}

Besides the Mag-Antsi dictionary that was developed by Storck and Storck (2005), no compilation of Mag-Antsi words was developed since then. To contribute to the preservation of Mag-Antsi language, this study constructed a word list of Mag-Antsi based on the narrations of Ayta beliefs, practices, and traditions. Mag-Antsi word list was analyzed morphologically to identify the grammatical structure of Mag-Antsi words. Additionally, through the help of the Mag-Antsi native speakers, oral narratives were developed into original Mag-Antsi cultural short stories.

\subsection{Research Objectives}

The primary aim of this study is to preserve the native language of Ayta Mag-Antsi in Central Luzon, Philippines.

Specifically, this study intended to achieve the following research objectives:

1. Create a word list in Mag-Antsi

2. Describe the internal structure of Mag-Antsi words

3. Develop Ayta Mag-Antsi cultural short stories

\section{Literature review}

\subsection{Oral Narratives and Culture}

An oral narrative is defined as a spoken story (Goldbelt Heritage Foundation, 2014). It is a story that people tell to share their deepest feelings, experiences, and knowledge. Oral narratives have been around for very long which the elderly use to share their own stories and traditions to their children and grandchildren so both their stories and traditions will continue to live and be remembered by younger generations.

Oral narratives are also used to learn about many things like history, science, and culture. One of the best ways to preserve a culture is through oral narratives. Using beads and other tangible objects, BaNtwane people of South Africa communicated through oral stories the meaning of handcrafted beadwork in their culture (Smith, Reitsma, Hoven, Kotze, 2011). Datta (2018) proved that traditional storytelling is a culturally appropriate method for indigenous research. Using storytelling as a method to communicate with indigenous and immigrant communities in Canada and Bangladesh, it empowered both the researcher and the participants by building trust between them. With the advancement of technology, the online archiving of oral narratives via audio and video recordings have been widely used nowadays to preserve cultures. Collecting, protecting, and connecting with endangered traditions have 
been the mission of the World Oral Literature Project that was established by the University of Cambridge in 2009 and by Yale University in 2011 (Turin, Wheeler, \& Wilkinson, 2012).

\subsection{Grammatical Structures of Indigenous Languages}

British Columbia indigenous languages are described as those with highly morphologically complex words in which a multi-word clause in English can only be expressed in one word making them 'polysynthetic'. Polysynthetic languages are highly synthetic with many morphemes in a single word. Polysynthetic languages also show 'noun incorporation' or 'lexical affixation'. The sentence 'He ruined her dress' is expressed as washakotya'tawitsherahetkvhta'se, a polysynthetic word in Mohawk, North America. Similarly, a single Yupik word kaipiallrulliniuk in Siberia and Alaska means 'the two of them were apparently really hungry' in English (Kell, 2014). American Indian languages are also polysynthetic. Complex ideas are expressed in a single-word sentence like in Lakota (Siouan) where wica-yuzaza-ma-ya-khiya-pi-kte which means "you all will make me wash them,". This single-word sentence is comprised of component morphemes 'them + wash + me + you + make + plural + future' (Welker, 1999).

Synthetic languages which are composed of words of several morphemes popularly describe French, Spanish, Persian, Lation, Russian, Greek, Arabic, Ukrainian, Navajo, Turkish, and Kanien'kéha (Mohawk). These synthetic languages display 1) relational synthesis - attaching bound morphemes to root words to show relationships between participants in a sentence; and/or 2) derivational synthesis joining various types of morphemes to create new words. Dene language in Alaska, for instance, has three morphemes in a word shqiztel - verb root iztet (kick) and two prefixes $s h$ - and $q$ - which means 'they kicked me'. In English, old English is more synthetic than modern English. Hence, modern English is described as 'moderately isolating' (Kell, 2014).

Although not considered polysynthetic, Eskayan language in Bohol, Southern Philippines, is marked by highly polysemous affixes (Kelly, 2011). Unlike Visayan language, Eskayan was full of morphosyntax ambiguities which led to the formation of analytical categories for this language.

Other languages are called isolating. Words of isolating languages mostly have one to two morphemes per word. Mandarin and Vietnamese are examples of isolating languages. Isolating languages put greater importance to context and sentence structure than to word structure. For instance, the Vietnamese sentence Người đó là anh nó only has one morpheme for each word (Kell, 2014).

Người đó là anh nó.

person that be brother he

"That person is his brother."

\subsection{Mag-Antsi as the Mother Tongue}

As an indigenous language, Mag-Antsi is regarded as stable for it is still existent in the community; however, it is noted that only the elders are speaking the language. Hence, the language calls for language maintenance (Tsunoda, 2006). Language maintenance (Fishman, 1964; as cited in Tsunoda, 2006), which is commonly known as language revitalization (Jones 1998; Reyhner 1999: iii; Spolsky 1995: 178; as cited in Tsunoda, 2006), is necessary for a language that is still existent, but only a few speak the language. The study intends to help the Ayta Mag-Antsi community attain at the Sustainable Literacy Level (Lewis, 2010) of language development in which Mag-Antsi would be used in all sectors of the society including the school. The present study takes a step forward in sustaining Mag-Antsi by developing readable and age-appropriate cultural short stories. 
This study likewise supports the Department of Education (DepEd) Oder No. 16 which states that the medium of instruction in teaching primary grade students should be the children's language. During the formative years, a child must be thought skills and concepts in schools using his/her home language. The right of the children to use their native language should be provided to them by the community, especially by the education sector. According to Article 5 of the 1960 Convention against Discrimination in Education, "the members of national minorities [have the right] to carry on their own educational activities, including... the use or the teaching of their own language, provided... that this right is not exercised in a manner which prevents the members of these minorities from understanding the culture and language of the community as a whole and from participating in its activities" (Ball, 2011).

Promoting the use of Mag-Antsi in different parts of the Ayta community particularly the school requires the use of their native language from Kindergarten to grade 3. In addition, majority of the textbooks to be used in schools should be written in Mag-Antsi, especially in their Mother-Tongue subject. The use of mother tongue in teaching has been proven effective in enabling children learn. Children learn better when using their home language than those who are learning using the second language (Macnamara, 1973; as cited in Senapati, Patnaik, \& Dash, 2012). In this light, the study of documenting Mag-Antsi through narratives is deemed beneficial in achieving the following goals: 1) promote the use Mag-Antsi (mother-tongue) in schools through their narratives; and 2) empower the children through their right to use their native language in schools; and 3) help preserve Mag-Antsi language using their documented narratives.

\subsection{Mag-Antsi Short Stories}

From 2015-2019, the graduate students from the University of the Philippines (UP) participated in the Big Book Project, a service learning activity of UP, which showcased short stories written in various languages in the Philippines including Mag-Antsi. Fifteen mothers from Ayta Mag-Antsi and 18 participants from Ayta Mag-Indi were trained to write short stories through book making workshops. The stories that the community participants created were based on a theme assigned to them. The students likewise participated in the project by drawing images that illustrate the stories. All stories were written in their mother tongue and were translated to Filipino (Arzadon, 2020).

\section{Method}

The present study adhered to sequential mixed methods research design (Creswell, 2009) beginning with a qualitative data collection and followed by quantitative and qualitative data analysis. The data were first gathered qualitatively through in-depth interviews with the Ayta Mag-Antsi community elders. Oral narratives in Mag-Antsi were sought from the participants by asking them to share their local traditions, beliefs, and practices using their native language. The oral narratives were transcribed and counted according to the frequently used words. Each of the words used in the narratives was translated into Filipino and was qualitatively analyzed for their lexical categories.

After the morphological analysis of Mag-Antsi words, the second phase of the study focused on the development of Mag-Antsi short stories. The oral narratives initially lacked narrative elements such as the setting, characters, plot, and theme; accordingly, these elements were featured in the development of 10 cultural short stories. To capture the authenticity of the shared narratives, Mag-Antsi words, narrative content, and their overall essence were taken as the sole source of cultural short stories that were developed. Additionally, these cultural short stories were carefully developed by five community adults led by an Ayta elementary teacher who can speak and write in Mag-Antsi. The collaborative 
efforts of the community members of writing cultural short stories is regarded as useful in getting younger Ayta Mag-Antsi learners more familiar with their native language and their culture.

\subsection{Sample / Participants}

The study involved Ayta Mag-Antsi community elders from five localities in Bamban, Tarlac: 1) Malasa, 2) San Martin, 3) Sta. Rosa, 4) Burog, and 5) Buok.

Three community elders from each locality, or a total of 15 participants took part in the study. The community elders, 60 years old and above, are all speakers of Mag-Antsi but due to lack of formal education, they cannot write in Mag-Antsi. In groups, the study participants were interviewed in Bamban, Tarlac to record their oral narratives. As requested, the study participants shared their cultural beliefs, traditions, practices, and past experiences using their native language. The Ayta Mag-Antsi community elders who are residing in other Sitios were requested to go to the designated venue in the community day care center for the convenience of the majority.

\subsection{Instrument $(s)$}

The study made use of an online word frequency counter to identify the most frequently used words in Mag-Antsi that emerged from the oral narratives of Ayta Mag-Antsi community elders. The frequently used words were tabulated according to their occurrence in the narratives which made up the Mag-Antsi word list.

\subsection{Data collection and analysis}

The initial data were gathered by going to the designated venues set by the Ayta Mag-Antsi community elders. In-depth interviews with the participants took place between December and April 2018. The study participants were requested to respond to the interview using their mother tongue (MagAntsi) to authentically record not only their culture, but also their language.

Gathered oral narratives were translated to Filipino (Tagalog) for data analysis. A grade school Ayta teacher, who is literate both in Mag-Antsi and Filipino, transcribed and translated the narratives to Filipino.

After the translation, most frequently used words were identified using a word frequency counter. From the identified frequently words used, a Mag-Antsi word list was constructed. Through the guidance of an Ayta Mag-Antsi teacher and the researcher, cultural short stories were also developed by the community people themselves by considering the words, content, and essence of the original oral narratives and by adding the narrative elements such as the setting, characters, plot, and theme.

The Mag-Antsi word list was analyzed in reference to its grammatical structure. Specifically, the words were analyzed through their 1) lexical categories; 2) individual morphemes and affixations; 3 ) and their similarities and/or differences with Filipino.

\section{Results and Discussion}

Table 1. Lexical categories of Mag-Antsi words

\begin{tabular}{|cc|}
\hline LEXICAL CATEGORIES OF MAG-ANTSI WORDS & NUMBER \\
\hline Content Words (nouns, verbs, adjectives, adverbs) & 261 \\
\hline $\begin{array}{c}\text { Function Words (pronouns, articles, prepositions, } \\
\text { interjections) }\end{array}$ & 115 \\
\hline TOTAL NUMBER & 376 \\
\hline
\end{tabular}


A total of 376 Mag-Antsi words were identified from the oral narratives with varied lexical categories. Table 1 shows that two hundred sixty-one of these words were content words while 115 were function words. One hundred seven of the content words were verbs, followed by 98 nouns, 22 adjectives, 23 adverbs, and 11 multi-functional words. The rest were function words composed of pronouns, prepositions, articles, and auxiliary verbs.

Mag-Antsi word list (See appendices: Table 1) which stemmed from the oral narratives of the community elders from Bamban, Tarlac was composed of Filipino and English translations. The word list shows that Mag-Antsi language has several synonymous words. For instance, the conjunction when (English) or kapag (Filipino) is known as huston/istun/potan in Mag-Antsi. The noun sweet potato (English) or kamote (Filipino) is known as kamotsi/kamatsing in Mag-Antsi. Also, the demonstrative pronoun there (English) or doon (Filipino) is termed bayro/bayru/ruon in Mag-Antsi. With the same meaning, bayro and bayru are almost identical in pronunciation and orthography with the only difference in the final vowel. Additionally, the adverb no (English) or hindi (Filipino) is termed in MagAntsi as ahe/aya/alwan. The initial vowel of these words is the same with deviations in the succeeding syllable.

Inflections were found existent in Mag-Antsi because the language is spoken by community elders from different sitios due to various morphs attached to Mag-Antsi words. Another cause of these inflections is multilingualism that is present in Ayta communities. Several Mag-Antsi words were used interchangeably with Filipino words. The word matsibi is used interchangeably with atake (attack). This is also true for maryarin or mangyari (to happen), and ulaga or mahalaga (important) with noticeable uniformity in the last two syllables.

Similar to Filipino, Mag-Antsi language has a unique orthography because of affixations. In MagAntsi, kultura (culture) is spelled as kulturan which appeared as a combination of the root kultura (culture) and a suffix - n. Lumabas (went out) is spelled in Mag-Antsi either as umawah or umaway. The difference lies in the final consonants $\boldsymbol{- h}$ and $\boldsymbol{y}$. The article $\boldsymbol{m g} \boldsymbol{a}$ (the) is spelled either as law or $\boldsymbol{a w}$. The word can be used with or without the initial consonant $-l$. Also, the prefix $\boldsymbol{n a}$ in Filipino is used either as $y \boldsymbol{a n}$ or $y \boldsymbol{a n g}$, with the final consonant or a suffix $-\boldsymbol{g}$ attached to the root $\boldsymbol{y a n}$ in several instances.

The grammatical structure of several Mag-Antsi words were found closely akin to Filipino words. Dumating (came) in Filipino is lumating in Mag-Antsi with a difference in the initial consonant. Babayi in Mag-Antsi is babae (girl) in Filipino which differ in the final vowel. Similarly, pwede (possible) in Filipino is pwedi in Mag-Antsi which contrast in the final vowel. Asawa (spouse) in Filipino is ahawa in Mag-Antsi. The difference lies only in the consonant next to the initial vowel. Bumukod (to live separately) in Filipino is magbukod in Mag-Antsi. In Mag-Antsi, the prefix mag- is attached to the root word bukod, while the infix -um- comes in the middle of the root word bukod in Filipino.

Apparently, there were words from the list which did not have Mag-Antsi counterpart. Along with Mag-Antsi, some Filipino and several English words were articulated by Ayta elders as evident in their oral narratives, thus code-switching in Mag-Antsi, Filipino, and English was interestingly noted in this study. The Filipino words used were anak (child), panahon (weather), datu (chieftain), bilang (count), ako (I, me), pasasalamat (thankfulness), pamilya (family), panganib (danger), paniniwala (belief), ninuno (ancestor), desisyon (decision), and bawal (prohibited) among others. Several English words that the participants used were chieftain, signal, basket, and center. It revealed that the elderly participants have knowledge, though not formal, of both Filipino and English. It can be deduced that not only the young generations of Aytas in Bamban, Tarlac are multilingual, but also the older generations. 
Table 2. Mag-Antsi narratives

\begin{tabular}{|c|c|}
\hline Written Narratives & Theme of the Story \\
\hline 1 Chief Hasgel & $\begin{array}{l}\text { A spiritual being warns the Aetas in an upcoming } \\
\text { danger which saves the people from being harmed. }\end{array}$ \\
\hline 2 Filial Responsibility & $\begin{array}{l}\text { The father as the head of the family protects the family } \\
\text { from any danger while the mother is responsible in } \\
\text { taking care of the children. }\end{array}$ \\
\hline 3 Fixed Marriage & $\begin{array}{l}\text { One of the Aetas' traditions is fixed marriage in which } \\
\text { the marriage of two young Aetas are arranged by their } \\
\text { families especially when a young man touches the heel } \\
\text { of a young woman. }\end{array}$ \\
\hline 4 Foods That Don't Go Well Together & $\begin{array}{l}\text { Aetas believe that shrimps, chili, and tomatoes must } \\
\text { not be mixed as these foods cause stomach ache to } \\
\text { those who would eat them. }\end{array}$ \\
\hline 5 The Dowry & $\begin{array}{l}\text { A dowry is given by the family of the man to the } \\
\text { family of his fiancée as a symbol of respect towards } \\
\text { the woman's family. }\end{array}$ \\
\hline 6 The Cravings of a Pregnant Mother & $\begin{array}{l}\text { Aetas believe that a pregnant mother's cravings should } \\
\text { not be ignored; otherwise, something harmful will } \\
\text { happen to the child in her womb. }\end{array}$ \\
\hline 7 A Message from the Sky & $\begin{array}{l}\text { Aetas believe that everyone should listen to the } \\
\text { message of the environment or else, something } \\
\text { unfortunate will happen to those who fail to listen. }\end{array}$ \\
\hline 8 Spirit in the Tree & $\begin{array}{l}\text { Aetas believe that spirits live in the tree. Therefore, no } \\
\text { one should disturb nor ruin the home of the spirits or } \\
\text { something bad will happen to those who dare to do it. }\end{array}$ \\
\hline 9 Vigilance & $\begin{array}{l}\text { Aetas believe that the coconut skin can protect them } \\
\text { against the deadly lightning during storms. Anyone } \\
\text { who fails to prepare himself for the calamity is putting } \\
\text { himself in danger. }\end{array}$ \\
\hline 10 Wedding Rites & $\begin{array}{l}\text { Aetas' wedding rites include having the married } \\
\text { couple pass across two spears that are crossed to one } \\
\text { another. This symbolizes a lasting marriage between } \\
\text { the married couple. However, anyone who cheats } \\
\text { between them will be killed using any of the two } \\
\text { spears used during the wedding ceremony. }\end{array}$ \\
\hline
\end{tabular}

Table 2 shows the cultural short stories that were developed based on the consolidated oral narratives of the Ayta Mag-Antsi community elders. A total of 10 brief short stories were created which depict the beliefs and traditions of Ayta Mag-Antsi. These narratives revolve around Aytas' beliefs about spirits, the power of the environment, food, as well as marriage and family traditions. Compared to other previously developed big books written in Mag-Antsi (Arzadon, 2020), these short stories mirror the rich culture of Ayta Mag-Antsi which should be documented and preserved.

\section{Conclusions}

The verbal morphology of Mag-Antsi is marked by complexity in two aspects: 1) the use of affixations (prefixes, infixes, and suffixes) attached to the root; and 2) the close similarity in grammatical features of some Mag-Antsi and Filipino words. 
Mag-Antsi, despite its complex verbal morphology, is more of an isolating than a polysynthetic language. Although affixations are noticeable in most Mag-Antsi words used in the narratives, morphemes are either one or two in every word.

Mag-Antsi word list shows the multilingual features of the language with the occurrence of MagAntsi, Filipino, and English words. The multilingual feature of Mag-Antsi is attributed to the nomadic nature of the Aytas. Even though most of them have not had formal education, they can speak more than two languages. They used a combination of Mag-Antsi, Filipino, and Kapampangan during casual talks and seldom include several English words in their utterances. Code-switching among Ayta Mag-Antsi community elders was observed during the course of their narration where they used the said languages together despite the request to speak in their native language. It was also noted during interviews that the Ayta Mag-Antsi community elders can fluently use Filipino at a sentential level while they can speak English at a word level.

The findings about the variations in words used in Mag-Antsi oral narratives were brought by the migration of the Aytas from various provinces in Luzon when Mount Pinatubo erupted in 1991. As they were relocated to different places, they become exposed to various languages as well.

In Bamban, Tarlac, fluent Mag-Antsi speakers are mostly the elderly, while the children speak either Kapampangan or Filipino. Hence, Mag-Antsi has become a minority rather than a majority language. While it is still safe to consider Mag-Antsi as a stable language, the whole community must aim to make their native language not only stable, but sustainable. It is therefore significant that the exposure of the entire community to their native language be intensified. The use of Mag-Antsi at home must be supported by the school by using the home language as a medium of instruction, which should also be evident in the books that they are using in school. As it is unfortunate that Mag-Antsi is not currently used as the language of academic books for the Aytas nor is widely documented for future reference, the development of cultural short stories serves as a preliminary step towards the preservation of MagAntsi and that of their rich culture. Cultural short stories may be read by Ayta children at home or in school which are great avenues to substantially expose them to their language and culture. This study, therefore, gives primary importance to the students and children who are the members of the community that are more capable of keeping their indigenous language alive; thus, the children learning the language will save the minority language from being extinct (Sorace, 2016).

\section{Ethics Committee Approval}

The author(s) confirm(s) that the study does not need ethics committee approval according to the research integrity rules in their country (Date of Confirmation: December 11, 2020).

\section{Acknowledgements}

The authors extend their gratitude to everyone who provided their valuable support in the accomplishment of the study:

To the UST Research Center for Social Sciences and Education (RCSSED) for the financial assistance given to complete this study;

To the community participants for sharing their time, resources, and stories to make this study possible; To Principal Nolan Aquino of Burog Elementary School, for allowing the researchers to conduct the study in his jurisdiction;

To Dr. Rosalyn Mirasol and Asst. Prof. Racquel Jimenez for their support in documenting Mag-Antsi language 


\section{References}

Alegre, H. (2008). Readability of mathematical texts. Philippine Normal University.

Arzadon, M. (2020). Making mother tongue big books through university-community partnerships. Mother Tongue Based Multilingual Education (MTB-MLE) Philippines.

Ball, J. (2011). Enhancing learning of children from diverse cultural backgrounds. UNESCO. 10-11. http://unesdoc.unesco.org/images/0021/002122/212270e.pdf

Datta, R. (2018). Traditional storytelling: An effective indigenous research methodology and its implications for environmental research. AlterNative: An International Journal of Indigenous Peoples, 14(1),35-44.

Table of languages. (2011). Ethnic Group Philippines. Retrieved from http://www.ethnicgroupsphilippines.com/people/table-of-languages/

Gunning, T.G. (2003). Building literacy in the content areas. Boston: Allyn \& Bacon.

Guidelines on the implementation of mother-tongue based multilingual education. (2012). Department of Education. Retrieved from: http://www.deped.gov.ph/orders/do-16-s-2012

Iseke, J. (2013). Indigenous storytelling as research. International Review of Qualitative Research, 6, $559-577$.

Kell, S. (2014). Polysynthetic language structures and their role in pedagogy and curriculum for BC indigenous languages: Final report. Retrieved from https://www2.gov.bc.ca/assets/gov/education/administration/kindergarten-to-grade-12/indigenouseducation/research/polysynthetic_language.pdf

Lewis, M.P. \& Simons, G.F. (2016). Sustaining language use: Perspectives on community-based language development. Dallas, Texas, USA: SIL International.

Nacmara, D. S. (2007). Reading comprehension studies: Theories, interventions, and technologies. Mahwah, New Jersey: Lawrence Erlbaum Associates, Inc.

Reading for information: Oral narratives. (2014). Goldbelt Heritage Foundation. Retrieved from: http://www.goldbeltheritage.org/wp-content/uploads/2014/05/DRA-34-What-is-an-Oral Narrative.pdf

Senapati, P., Patnaik, N., \& Dash, M. (2012). The role of medium of instruction in the cognitive processes. Journal of Education and Practice, 2(3). 58-66.

Smith, A., Reitsma, L., Hoven, E., \& Kotze, P. (2011). Towards preserving indigenous oral stories using tangible objects. 2011 Second International Conference on Culture and Computing, Kyoto University, Japan.

Storck, K., \& Storck, M. (2005). Ayta Mag-Antsi English dictionary. Summer Institute of Linguistics. Stories matter: Why stories are important to our lives and culture. (2020). TCK Publications.

Tsunoda, T. (2006). Language endangerment and language revitalization: An introduction. New York: Walter de Gruyter GmbH and Co.

Welker, G. (1999). History and discussion of indigenous languages. Retrieved from: https://www.indigenouspeople.net/language.htm 


\section{Sözcüklerden daha fazlası: Filipinler'deki yerli bir dilin dokümantasyonu ve morfolojik analizi}

\section{$\ddot{\mathbf{O} z}$}

Sözlerden daha fazlası anlatılacak hikayelerdir. Bu çalışma, Filipinler'deki Ayta Mag-Antsi yerli halkının ana dili olan Mag-Antsi'nin belgelenmesi ve analizi ile ilgilidir. Kalan konuşmacıları yaşlanan nüfusla birlikte, Mag-Antsi sürdürülebilir olmaktan çok uzak. Derinlemesine görüşmeler kullanılarak Ayta inançları, uygulamaları ve gelenekleri belgelendi ve çeşitli sözcük kategorilerine sahip 376 Mag-Antsi kelimesi içeren bir kelime listesi oluşturuldu. Sözlü anlatılarda Mag-Antsi kelimelerinin gramer yapısını yakalamak için Mag-Antsi'nin morfolojik bir analizi yapıldı. Ayta Mag-Antsi'nin farklı kültürünü belgelemek ve korumak için sözlü anlatılardan on kültürel kısa öykü de geliştirildi. Bu çalışma, Mag-Antsi dilinin morfolojik yapısının çekimler ve benzersiz bir imla ile işaretlenen Filipin diliyle bazı benzerlikleri olduğunu buldu. Bu çalışma aynı zamanda akademik ortamda ana dilin kullanımına ve dilin korunmasına ilişkin pratik çıkarımlar göstermektedir.

Anahtar Sözcükler: Mag-Antsi; Ayta Mag-Antsi; kelime listesi; kültürel kısa hikayeler; ana dil

\section{AUTHOR BIODATA}

Evalyn B. Abiog is an assistant professor at the University of Santo Tomas, Manila, Philippines under the auspices of the Department of English and the Faculty of Arts and Letters. She earned her Bachelor's Degree in Secondary Education, Major in English (2003), Master's Degree in Teaching English Language Arts (2006), and her Doctorate Degree in Reading Education (2017) from the Philippine Normal University, Manila. Currently, she is the Training and Community Engagement Officer of UST SIMBAHAYAN Community Development Office and the Coordinator of university-wide student organizations. She is also a research associate at the UST Research Center for Social Sciences and Education (RCSSED). In 2017, she published her research titled "The Experiences in Processing Policies and Contracts by Adult ESL Readers" at the Journal of English Language Teaching.

Rowena D. David is a public school teacher at Burog Elementary School in Bamban, Tarlac, Philippines. As an Ayta Mag-Antsi teacher, she is passionate in documenting and preserving her community's native language. She currently ranks as Teacher 1 in the said school. 